\title{
Efek Terpaan Video Iklan TV pada Citra Merek Platform E-commerce
}

\author{
Dessy Chatarina ${ }^{1}$, Stephanny Lianardo ${ }^{2}$ \\ 1, 2 LSPR Communication \& Business Institute, Jakarta, Indonesia
}

\begin{abstract}
ABSTRAK
Penelitian ini bertujuan untuk mengetahui dan menganalisis besarnya pengaruh terpaan iklan terhadap citra merek Shopee melalui iklan Shopee 9.9 Super Shopping Day Cristiano Ronaldo. Penelitian menggunakan metode deskriptif kuantitatif melalui penyebaran kuesioner kepada 100 orang responden yang pernah menonton iklan Shopee 9.9 Super Shopping Day Cristiano Ronaldo. Hasil penelitian menunjukkan bahwa terpaan iklan lebih berpengaruh positif terhadap citra merek Shopee melalui iklan Shopee Super Shopping Day 9.9 Cristiano Ronaldo kepada konsumen pria yang menunjukkan bahwa Shopee telah berhasil lepas dari citra platform yang identik dengan perempuan. PT. Shopee Internasional Indonesia perlu mempertahankan dan mengembangkan periklanan mereka untuk membentuk ketertarikan konsumen yang akan berdampak pada citra merek Shopee.
\end{abstract}

Kata kunci: terpaan iklan; iklan televisi; e-commerce; citra merek

\begin{abstract}
This research aims to find out and analyze the effect of advertising on Shopee's brand image through Cristiano Ronaldo's Shopee 9.9 Super Shopping Day ad. This research used quantitative descriptive research method by distributing questionnaires to 100 respondents who have watched Cristiano Ronaldo's Shopee 9.9 Super Shopping Day ad. The research result shows that Cristiano Ronaldo's Shopee 9.9 Super Shopping Day ad positively effects the male consumers more which shows that Shopee succeeds in escaping the image of platform for female. PT. Shopee Internasional Indonesia needs to maintain and develop their advertising in order to form consumers' interest which impact Shopee's brand image.
\end{abstract}

Keywords: advertising exposure; television advertising; e-commerce; brand image

\section{PENDAHULUAN}

Masyarakat Indonesia kini mulai aktif dalam melakukan jual beli online dimana internet berfungsi sebagai alat penghubung utama antara pedagang dan konsumennya. Hal ini ditunjukkan dalam Laporan Survei Digital 2020 dirilis oleh Kemp (2020) melalui Data Reportal yang menunjukkan shopping apps di peringkat menengah dengan persentase 55\% sebagai alasan utama penggunaan internet melalui telepon genggam. 
Gambar 1. Use of Mobile Apps by Category

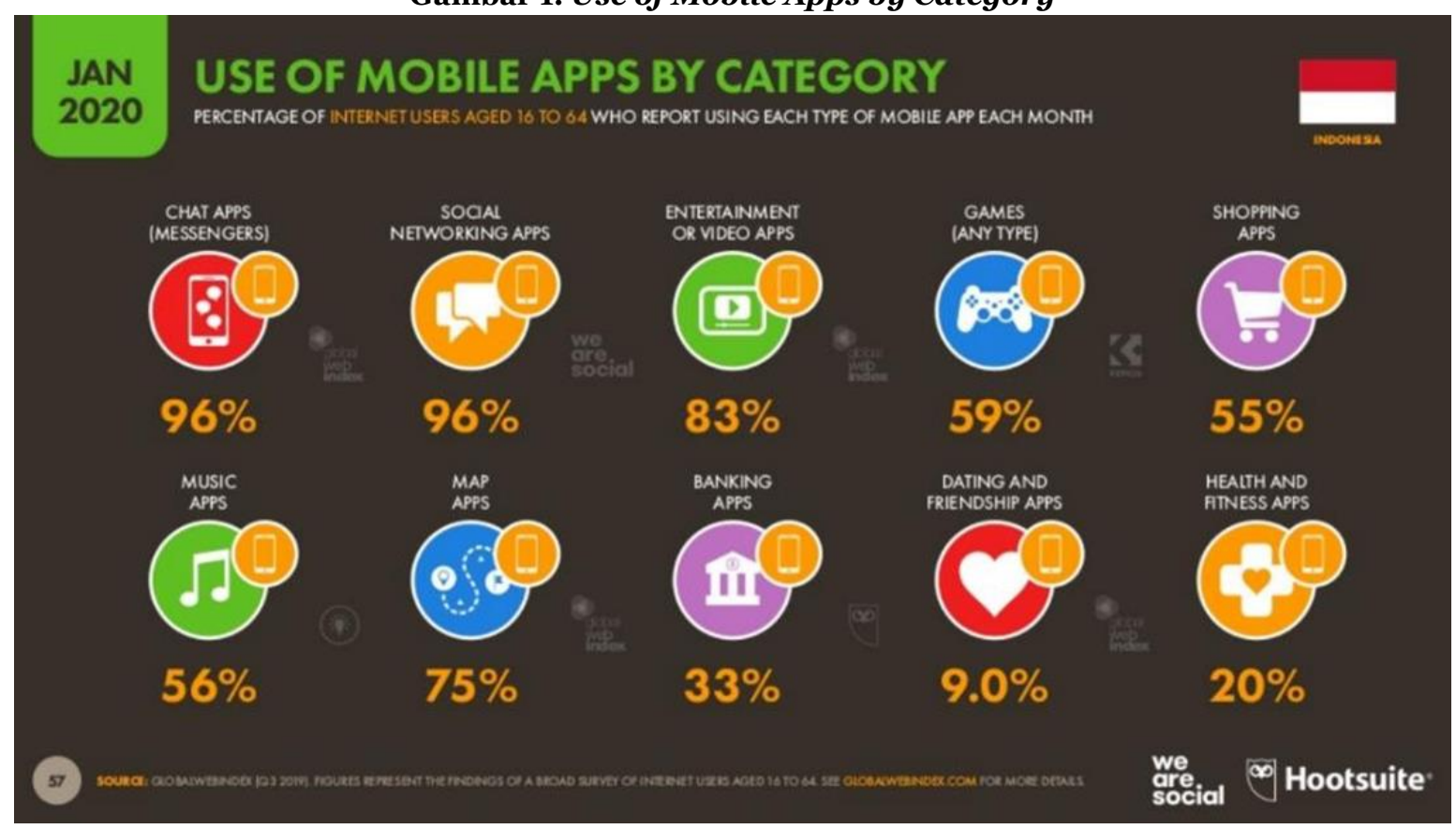

Sumber: Kemp (2020)

E-commerce masuk ke Indonesia sejak tahun 1996 dan mengalami pertumbuhan yang sangat pesat menghasilkan persentase perbandingan yang cukup signifikan dibanding dengan negara lain di seluruh dunia. Berdasarkan data yang dirilis oleh (Widowati, 2019) menunjukkan bahwa Indonesia memimpin pertumbuhan $78 \%$ pada 2018. Jumlah pengguna yang mencapai angka 100 juta menjadi salah satu faktor terdorongnya pertumbuhan $e$-commerce. Masyarakat Indonesia membelanjakan jumlah uang dengan rata-rata yang mencapai US\$ 228 atau 3,19 juta per orang pada situs belanja daring.

Tabel 1. Top Brand Index Retail Situs Jual Beli Online

\begin{tabular}{|lll|}
\hline Brand & TBI 2020 & \\
\hline Lazada.co.id & $41.0 \%$ & TOP \\
Shopee.com & $19.5 \%$ & TOP \\
Blibli.com & $13.2 \%$ & TOP \\
Tokopedia.com & $8.0 \%$ & \\
Bukalapak.com & $5.3 \%$ & \\
\hline \multicolumn{3}{|c|}{ Sumber: Top Brand Award (2020) } \\
\hline
\end{tabular}

Shopee menduduki peringkat kedua untuk situs jual beli online dengan kenaikan nilai TBI (Top Brand Index) sebesar 3.9\% dibandingkan tahun 2019 berdasarkan survei oleh Top Brand Award (2020). Penilaian Top Brand memilih merek terbaik oleh pelanggan Indonesia berdasarkan riset yang mengacu pada tiga parameter Top of Mind Share, Top of Market Share dan Top of Commitment Share. Shopee masih menduduki posisi ranking pertama dalam ratarata ranking aplikasi pada kuartal ketiga di tahun 2019 dengan jumlah pengunjung web bulanan sebanyak 55.964.700 orang (iPrice, 2019).

Shopee, aplikasi mobile commerce berbasis marketplace hadir di Indonesia pada Selasa 01 Desember 2015 diklaim sebagai aplikasi mobile marketplace pertama bagi konsumen-kekonsumen ( $\mathrm{C}_{2} \mathrm{C}$ ) didirikan oleh Chris Feng di bawah naungan Garena Group (sudah berganti 
nama menjadi SEA Group) dengan tagline-nya "Best Online Shopping Platform in Southeast Asia" memiliki tujuan mengubah dunia menjadi lebih baik dengan menyediakan platform untuk menghubungkan pembeli dan penjual dalam satu komunitas (Reza, 2015).

Rhesa Dwi Prabowo, Head of Communication, Hi-Tech and Media Industry MarkPlus, Inc menyebutkan Shopee menjadi top of mind brand e-commerce bagi para perempuan dengan persentase $56 \%$ dari sisi penjual dan 50,2\% dari sisi segmen berdasar dari hasil riset yang dilakukan dengan meliputi sampel sekitar 1.200 orang dari wilayah Pulau Jawa, Sumatera, Kalimantan, sampai Bali menunjukkan bahwa Shopee memiliki posisi sebagai brand $e$ commerce yang memberdayakan perempuan baik dari sisi konsumen maupun penjual (Soenarso, 2019).

Cristiano Ronaldo resmi diumumkan sebagai Brand Ambassador terbaru skala internasional pada Rabu 14 Agustus 2019 Shopee dalam menghadirkan berbagai inisiatif untuk merangkul dan menginspirasi masyarakat juga berdampak luas bagi pengguna Shopee. "Dengan kolaborasi ini, kami melihat sosok Cristiano Ronaldo inspiratif dan sebagai salah satu pemain sepak bola terbaik sepanjang masa" kata Handika Jahja di The Tribata, Kebayoran baru, Jakarta Selatan (Sari, 2019). Dalam perannya sebagai Brand Ambassador untuk Shopee, sebuah video promosi dengan judul "Shopee 9.9 Super Shopping Day | Aksi Cristiano Ronaldo di Shopee".

Melalui Ronaldo, Shopee ingin lepas dari citra platform e-commerce yang identik dengan perempuan. Bagi Rezki sejak awal Shopee tidak ditujukan untuk satu jenis kelamin, namun untuk semua jenis kelamin. Upaya menepis stigma tersebut sudah beberapa kali dilakukan Shopee. Misalnya, dengan merilis portal Shopee for Men yang khusus untuk produk-produk yang berkaitan dengan dunia pria. (Triwijanarko, 2019).

Penelitian ini dilakukan berdasar dari permasalahan mengenai Shopee yang berniat lepas dari citra platform $e$-commerce yang identik dengan perempuan dan memberikan dampak positif kepada pengguna Shopee. Penulis bermaksud untuk mengetahui perbedaan rata-rata pengaruh terpaan iklan versi Shopee 9.9 Super Shopping Day Cristiano Ronaldo terhadap citra merek Shopee antara konsumen pria dan wanita, serta menganalisis besarnya pengaruh terpaan iklan versi Shopee 9.9 Super Shopping Day Cristiano Ronaldo terhadap citra merek Shopee pada konsumen wanita dan juga pada konsumen pria melalui penelitian ini.

\section{TEORI DAN KONSEP}

\section{Terpaan Iklan (Advertising Exposure Model)}

Batra mempopulerkan model terpaan iklan dimana terpaan iklan merupakan salah satu dari beberapa proses efek periklanan dalam The Communication and Persuasion Process. The Communication and Persuasion Process adalah satu faktor yang perlu dipertimbangkan dalam membuat rencana periklanan untuk rencana pemasaran. Terpaan iklan Menurut Batra et al. (2006, P. 62-63) proses terpaan iklan memiliki lima tahapan, yakni: paparan iklan dapat menciptakan kesadaran tentang merek, yang mengarah ke perasaan keakraban dengannya; informasi tentang manfaat merek dan atribut yang menjadi dasar manfaat dapat didaftarkan dengan konsumen juga dapat dihasilkan dari paparan iklan; iklan juga bisa menimbulkan perasaan di antara khalayak bahwa mereka mulai terhubung dengan merek atau tingkat konsumsinya; , iklan dapat mengarah kepada penciptaan gambaran untuk merek, yang disebut "kepribadian merek" melalui pemilihan juru bicara dan berbagai perangkat 
pelaksana; serta iklan menciptakan kesan bahwa merek disukai oleh sekelompok konsumen, atau para ahli-individu dan kelompok dari konsumen yang suka ditiru.

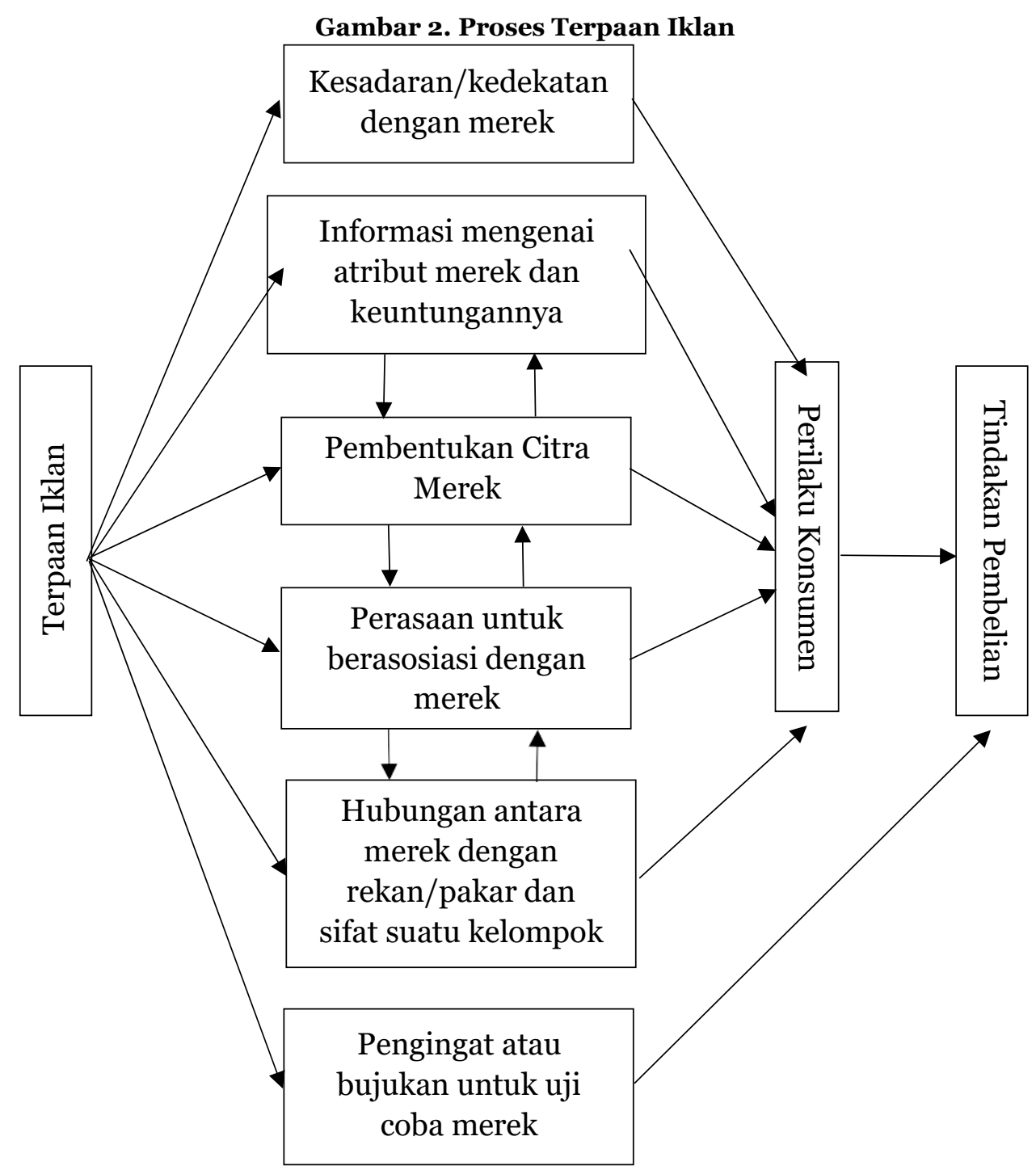

Sumber: Batra et al., (2006, p. 63)

Lima efek ini bisa menciptakan kecintaan, atau sikap, terhadap merek, yang mengarah pada tindakan pembelian yang sering disebut sebagai terpaan iklan. Terpaan terjadi jika penempatan iklan dilakukan agar calon pembeli dapat melihat (see), mendengar (hear) atau membaca (read) iklan tersebut. Penentuan terpaan dapat dilihat dari dari frekuensi, intensitas, dan durasi. (Nurbani, 2016, p. 15).

Frekuensi adalah seberapa sering iklan dilihat, dibaca, dan didengarkan. Frekuensi yang tinggi mengakibatkan pesan dari iklan menempel dalam benak konsumen dan mendapat perhatian dari konsumen.

Intensitas mengukur seberapa pemahaman khalayak atas isi pesan iklan. Dalam hal ini intensitas yang diteliti merupakan iklan televisi maka dilihatlah unsur audio dan videonya.

Durasi merupakan lama iklan dilihat, dibaca, dan didengarkan. Pola durasi dipilih berdasarkan faktor anggaran periklanan, siklus konsumen, dan strategi bersaing. 
Tabel 2. Dimensi dan Indikator dari Variabel Terpaan Iklan

\begin{tabular}{ccl}
\hline Variabel & Dimensi & \multicolumn{1}{c}{ Indikator } \\
\hline Terpaan Iklan (X) & Frekuensi & $\begin{array}{l}\text { a. tingkat keseringan melihat iklan } \\
\text { b. tingkat keseringan menonton iklan }\end{array}$ \\
\hline & Intensitas & $\begin{array}{l}\text { a. Pesan iklan mudah dipahami } \\
\text { b. Iklan menarik untuk ditonton }\end{array}$ \\
\hline Durasi & $\begin{array}{l}\text { a. Lama melihat iklan } \\
\text { b. Lama menonton iklan }\end{array}$ \\
\hline Sumber: Nurbani (2016, p. 15)
\end{tabular}

\section{Citra Merek (Brand Image)}

Firmansyah (2019) menjelaskan bahwa citra merek atau brand image sebagai persepsi konsumen tentang suatu merek dimana berdasarkan memori konsumen tentang suatu produk, dimana berdasarkan memori konsumen tentang suatu produk sebagai akibat dari apa yang dirasakan oleh seseorang terhadap merek tersebut. Selain itu, Simamora (2002, p. 92) mengungkapkan citra merek sebagai interpretasi akumulasi berbagai informasi yang diterima konsumen.

Ada 3 komponen pembentuk brand image yang dikemukakan oleh Rita (2019), yaitu citra pembuat (corporate image), citra pemakai (user image), dan citra produk (product image). Penelitian ini berfokus citra merek Shopee sebagai perusahaan yang membuat jasa (corporate image).

Dalam meneliti citra merek, ada tiga dimensi yang digunakan sebagai indikator yakni tingkat dikenalnya sebuah merek oleh konsumen (pengenalan/recognition); tingkat reputasi atau status yang cukup tinggi dari sebuah merek atas track record yang baik (reputasi/reputation); emotional relationship yang timbul antara sebuah merek dengan konsumennya yang bisa dilihat dari harga, kepuasan konsumen dan tingkat asosiasi (daya tarik/affinity); dan besarnya kesetiaan konsumen dari suatu produk atau jasa merek tertentu yang digunakan (kesetiaan/loyalty). (Rangkuti, 2009, dalam Indrasari, 2019, p.100). Perdana (2010) dalam Indrasari (2019, p. 102) memaparkan bahwa indikator citra merek adalah image yang positif.

Penulis menggunakan dimensi Pengenalan, Reputasi, dan Daya Tarik untuk menguji tingkat efek terpaan iklan terhadap tingkat dikenalnya merek, tingkat reputasi dan emotional relationship yang berdampak pada citra merek Shopee pada konsumen pria dan wanita. Adapun rumusan indikator citra merek sebagai berikut: (a) mengenal merek tersebut; (b) merek yang terpercaya; (c) merek yang berkualitas; (d) menimbulkan rasa suka; (e) kesan yang baik; (f) merek yang populer; dan (g) harga yang sesuai.

Tabel 3. Dimensi dan Indikator dari Variabel Citra Merek

\begin{tabular}{ccl}
\hline Variabel & Dimensi & \multicolumn{1}{c}{ Indikator } \\
\hline Citra Merek (Y) & $\begin{array}{c}\text { Pengenalan } \\
\text { (Recognition) }\end{array}$ & $\begin{array}{l}\text { a. Merek yang populer } \\
\text { b. Merek mudah diingat }\end{array}$ \\
\hline & $\begin{array}{c}\text { Reputasi } \\
\text { (Reputation) })\end{array}$ & $\begin{array}{l}\text { a. Merek yang terpercaya } \\
\text { b. Merek yang terpercaya }\end{array}$ \\
\hline
\end{tabular}




\begin{tabular}{ll}
$\begin{array}{ll}\text { Daya Tarik } \\
\text { (Affinity) }\end{array}$ & $\begin{array}{l}\text { a. Merek yang terpercaya } \\
\text { b. Pelayanan memuaskan } \\
\text { c. Kesan yang baik }\end{array}$ \\
\hline Sumber: Rangkuti (2009) dan Perdana (2010) dalam Indrasari, M. (2019, p. 102)
\end{tabular}

Berdasarkan uraian teori dan konsep di ataas, maka dapat dirumuskan hipotesis seabagai berikut:

$\mathrm{H}_{\mathrm{o}}$ : Tidak ada perbedaan rata-rata pengaruh terpaan iklan terhadap citra merek Shopee antara konsumen pria dan wanita.

$\mathrm{H}_{\mathrm{o1}}$ : Tidak ada pengaruh terpaan iklan terhadap citra merek Shopee pada konsumen wanita.

$\mathrm{H}_{\mathrm{o} 2}$ : Tidak ada pengaruh terpaan iklan terhadap citra merek Shopee pada konsumen pria.

$\mathrm{H}_{1}$ : Terdapat perbedaan rata-rata pengaruh terpaan iklan terhadap merek Shopee antara konsumen pria dan wanita.

$\mathrm{H}_{2}$ : Terdapat pengaruh terpaan iklan terhadap citra merek Shopee konsumen wanita.

$\mathrm{H}_{3}$ : Terdapat pengaruh terpaan iklan terhadap citra merek Shopee konsumen pria.

\section{METODE PENELITIAN}

Pada penelitian ini populasi ditentukan berdasarkan pernyataan dari Chris Feng sebagai CEO Shopee yang dilansir oleh Cicilia (2019, para. 3) dalam jumpa persnya terkait iklan TV Shopee yang menampilkan Cristiano Ronaldo sebagai duta mereknya telah mendapatkan 35 juta online viewer dengan peningkatan jumlah pesanan sebanyak tiga kali lipat dibandingkan tahun 2018.

Selain itu penentuan populasi juga didasari oleh pernyataan mengenai pengguna $e$-commerce yang didominasi oleh anak muda dengan rentang usia 15-34 tahun sebanyak 80\% yang dipaparkan oleh Sugiarto dalam Tashandra (2018). Maka dari itu jumlah populasi dalam penelitian ini adalah jumlah viewer iklan TV Shopee sampai tanggal 29 September sebanyak 35.000.000 orang dengan rentang usia 15-34 tahun.

Penelitian ini menggunakan pendekatan kuantitatif dengan paradigma positivistik dari sampel 100 orang pengguna aplikasi Shopee berusia 17-34 tahun yang berdomisili di DKI Jakarta dan sudah pernah menonton video promosi Shopee 9.9 Super Shopping Day 9.9 Cristiano Ronaldo berdasarkan jumlah pengunjung bulanan website Shopee. Sampel diambil menggunakan metode purposive sampling, dalam hal ini satuan sampling dipilih atas pertimbangan untuk memperoleh satuan sampling dengan karakteristik yang dikehendaki. (Setiawan, 2005).

Dalam penelitian ini, penulis memperoleh data primer melalui hasil kuesioner yang disebar ke responden dengan menggunakan pengukuran skala Likert. Skala Likert menjabarkan variabel yang akan diukur menjadi indikator variabel. Untuk keperluan analisis kuantitatif, tiap pilihan jawaban yang tersedia diberi nilai sebagai berikut: SS (Sangat Setuju) dengan bobot skor 5; S (Setuju) dengan bobot skor 4; RR (Ragu-ragu) dengan bobot skor 3; TS (Tidak Setuju) dengan bobot skor 2; dan STS (Sangat Tidak Setuju) dengan bobot skor 1. Sedangkan untuk data sekunder, memperoleh dari sumber literatur seperti buku, artikel jurnal, dan hasil penelitian sebelumnya terkait dengan topik penelitian ini. 
Untuk menganalisa hasil kuesioner yang sudah disebar, penulis menggunakan analisa statistik deskriptif yang mana menggambarkan data, baik dengan tabel, grafik, maupun ringkasan data. (Anwar, 2009, p. 47).

Penelitian ini bertujuan untuk mengetahui pengaruh terpaan iklan terhadap citra merek dan juga perbedaan pengaruhnya antara wanita dan pria. Pengaruh terpaan iklan terhadap citra merek dianalisa menggunakan uji korelasi yang merupakan studi yang membahas derajat hubungan atau derajat asosiasi antara dua variabel atau lebih dengan skala tertentu yang diukur dengan jarak sampai dengan 1. (Arifin, 2017, p. 135).

Sedangkan, untuk mengetahui hubungan linier antara dua variabel, digunakanlah model probabilistik untuk regresi linear sederhana yang di mana salah satu variabel, dalam penelitian ini berupa terpaan iklan (X) dianggap mempengaruhi variabel citra merek (Y) dengan rumus sebagai berikut (Suyono, 2018):

$\mathrm{Y}=\beta+\beta \mathrm{X}+\varepsilon$

Keterangan:

$\mathrm{Y}=$ Terpaan Iklan

$\beta=$ Koefisien Regresi

$\mathrm{X}=$ Citra Merek

$\mathrm{E}=$ Error

Berdasarkan variabel penelitian yang dijabarkan di atas, maka dapat digambarkan skema penelitian sebagai berikut:

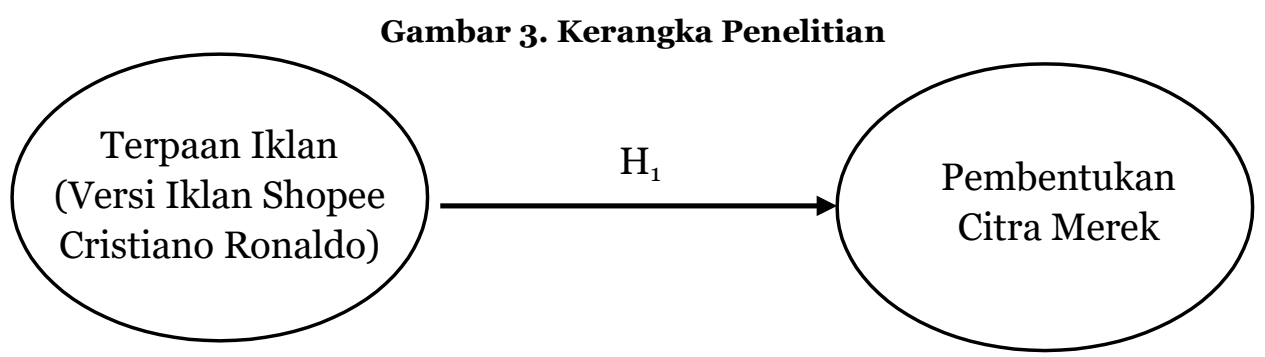

Sumber: Data olahan penulis (2020)

\section{HASIL DAN PEMBAHASAN}

Respondensi dalam penelitian ini diperoleh melalui penyebaran kuesioner pada pengguna aplikasi Shopee berusia 17-34 tahun yang berdomisili di DKI Jakarta dan sudah pernah menonton video promosi Shopee 9.9 Super Shopping Day 9.9 Cristiano Ronaldo. Jumlah kuesioner yang disebar dan diproses adalah sebanyak 100 respon kuesioner.

Instrumen dalam penelitian ini terlebih dahulu diuji dengan menyebarkan kuesioner pre-test pada 30 responden. Instrumen yang diuji meliputi pernyataan yang mencakup variabel $\mathrm{X}$ sebanyak 8 butir dan variabel Y yang mencakup 9 butir pertanyaan.

Uji validitas dilakukan untuk menentukan valid atau tidaknya instrumen. Instrumen dikatakan valid apabila Nilai positif dan $\mathrm{r}_{\text {hitung }}>\mathrm{r}_{\text {tabel }}$ maka item dapat dinyatakan valid, jika $\mathrm{r}_{\text {hitung }}<\mathrm{r}_{\text {tabel }}$ maka item dinyatakan tidak valid (Purnomo, 2017, p. 65). Dengan diketahui bahwa nilai $\mathrm{r}_{\text {tabel }}$ untuk $\mathrm{N}=30$ dengan nilai $\alpha=5 \%$ adalah 0,374 . 
Hasil uji validitas untuk 8 butir pernyataan dari variabel Terpaan Iklan (X) dan 9 butir pernyataan dari variabel Citra Merek (Y) dengan $r_{\text {tabel }}$ sebesar 0.374 untuk masing-masing butir pernyataan menunjukkan hasil $r_{\text {hitung }}$ dengan nilai lebih besar daripada $r_{\text {tabel }}$ pada tiaptiap butir yang diuji. Hal ini menyatakan bahwa seluruh instrumen variabel Terpaan Iklan (X) dan Citra Merek (Y) pada penelitian ini adalah valid.

Uji reliabilitas menunjukkan indeks yang mengindikasikan suatu alat ukur dapat dipercaya atau dapat diandalkan. Instrumen dapat dikatakan reliabel jika angka Cronbach's Alpha lebih dari o,6o (Payadnya \& Jayantika, 2018, p. 27). Hasil uji reliabilitas untuk 8 butir pernyataan dari variabel terpaan iklan (X) menunjukkan hasil o,916 dan untuk 9 butir pernyataan dari variabel citra merek $(\mathrm{Y})$ adalah 0,909. Hasil uji reliabilitas kedua variabel pada kuesioner pretest yang disebar kepada 30 responden semuanya menunjukkan nilai lebih dari o,6 sehingga dapat disimpulkan sebagai reliabel.

Uji normalitas dilakukan untuk menganalisis lebih lanjut mengenai apakah distribusi data bersifat normal atau tidak. (Arifin, 2017, p. 85). Penelitian ini menggunakan metode Komogorov-Smirnov Test untuk uji normalitasnya dengan dasar pengambilan keputusan distribusi data bersifat normal apabila nilai signifikasi (Sig,) lebih besar dari o,05 dan tidak normal apabila nilai signifikasi (Sig,) lebih kecil dari 0,05. (Raharjo, 2019).

Tabel 4. Hasil Uji Normalitas

One-Sample Kolmogorov-Smirnov Test

\begin{tabular}{llc} 
& & $\begin{array}{l}\text { Unstandardized } \\
\text { Residual }\end{array}$ \\
\hline $\mathrm{N}$ & & 93 \\
\hline $\begin{array}{l}\text { Normal Parameters } \\
\text { a,b }\end{array}$ & Mean & 0 \\
\hline & Std. & \\
& Deviation & 5,14373045 \\
\hline
\end{tabular}

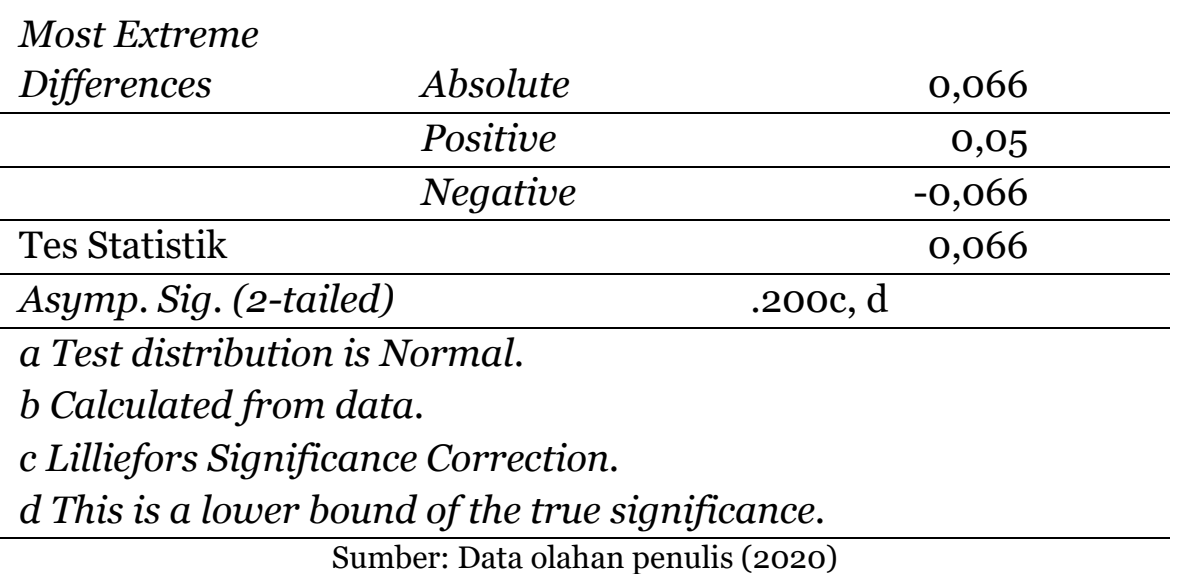

Tabel tersebut menampilkan data uji normalitas dengan hasil nilai Assymp. Sig. (2-tailed) 0,200>0,05 yang dapat disimpulkan bahwa data terdistribusi normal. 
Adapun karakteristik responden dalam penelitian ini adalah 50 orang berjenis kelamin lakilaki dan 50 orang perempuan dengan total responden 100 orang. Sedangkan pengelompokan responden berdasarkan kelompok usia dapat dilihat di tabel berikut:

Tabel 5. Karakteristik Responden

\begin{tabular}{lccc} 
& Wanita & Pria & Total \\
\hline 17-19 Tahun & 9 & 19 & 28 \\
\hline 20-24 Tahun & 33 & 24 & 57 \\
\hline 25-29 Tahun & 5 & 3 & 8 \\
\hline 30-34 Tahun & 3 & 4 & 7 \\
\hline Total & 50 & 50 & 100 \\
\hline & Sumber Data olahan penulis (2020)
\end{tabular}

Sesuai data yang tersaji dalam tabel karakteristik respon, dilihat bahwa responden survei ini didominasi oleh kalangan masyarakat berusia 20-24 tahun.

Adapun hasil dari kuesioner menunjukkan data rata-rata atas variabel Terpaan Iklan (X) dan dimensi-dimensinya sebagai berikut:

Tabel 6. Rata-rata Variabel Terpaan Iklan (X)

\begin{tabular}{clr}
\hline No & \multicolumn{1}{c}{ Dimensi } & Mean \\
\hline 1 & Frekuensi & 3,62 \\
\hline 2 & Intensitas & 3,32 \\
\hline 3 & Durasi & 2,81 \\
\hline Rata-rata & Variabel & 3,25 \\
\hline
\end{tabular}

Keterangan:

$4,21-5,00=$ Sangat tinggi

$3,41-4,20=$ Tinggi

$2,61-3,40=$ Cukup Tinggi

$1,81-2,60=$ Rendah

$1,00-1,80=$ Sangat rendah

Sumber: Data olahan penulis (2020)

Tabel di atas menunjukkan bahwa proses terpaan iklan Shopee Super Shopping Day 9.9 Cristiano Ronaldo cukup tinggi atau baik. Hal ini ditunjukkan dari hasil rata-rata variabel Terpaan Iklan yang diperoleh, yakni 3,25.

Rata-rata dimensi frekuensi dari data yang diperoleh menunjukkan nilai 3.62 yang tergolong tinggi menunjukkan pesan dari iklan menempel dalam benak konsumen dan mendapat perhatian dari konsumen. Rata-rata dimensi intensitas dengan nilai yang ditunjukkan sebesar 3,32 yang tergolong cukup tinggi menunjukkan bahwa responden cukup mengerti tentang isi pesan iklan. Selain itu, rata-rata dimensi durasi yang tergolong cukup tinggi dengan nilai 2,81 menunjukkan bahwa responden cukup sering melihat, membaca dan mendengarkan iklan. 
Untuk variabel Citra Merek (Y) dan dimensi-dimensinya didapatkan data rata-rata sebagai berikut:

\begin{tabular}{|c|c|c|}
\hline No & Dimensi & Mean \\
\hline 1 & Pengenalan & 4,36 \\
\hline 2 & Reputasi & 4,06 \\
\hline 3 & Daya Tarik & 3,94 \\
\hline \multicolumn{2}{|c|}{ Rata-rata Variabel } & 4,12 \\
\hline
\end{tabular}

Keterangan:

$$
\begin{aligned}
& 4,21-5,00=\text { Sangat tinggi } \\
& 3,41-4,20=\text { Tinggi } \\
& 2,61-3,40=\text { Cukup Tinggi } \\
& 1,81-2,60=\text { Rendah } \\
& 1,00-1,80=\text { Sangat rendah } \\
& \text { Sumber: Data olahan penulis }(2020)
\end{aligned}
$$

Rata-rata dimensi pengenalan tergolong sangat tinggi dengan nilai 4,36 menunjukkan bahwa merek Shopee sangat dikenal baik oleh konsumen. Rata-rata dimensi Reputasi tergolong tinggi dengan nilai 4,06 menunjukkan track record Shopee di mata konsumen tergolong baik. Namun pada pernyataan "Shopee selalu menyediakan brang-barang yang berkualitas" dengan rata-rata 3,79 menunjukkan bahwa reputasi barang berkualitas Shopee masih kurang dikenal oleh responden.

Rata-rata dimensi Daya Tarik menunjukkan nilai 3,94 yang tergolong tinggi menunjukkan Emotional Relationship yang timbul antara merek Shopee dengan konsumen tergolong baik. Pada pernyataan "Pelayanan Shopee dalam mengatasi masalah sangat memuaskan" dengan rata-rata 3,83 dan "Secara keseluruhan pelayanan di Shopee melebihi harapan saya" dengan rata-rata 3,86 menunjukkan bahwa pelayanan Shopee dalam posisi cukup baik.

Untuk meneliti hubungan antara kedua variabel, penulis melakukan uji korelasi dengan menggunakan rumus Pearson dengan hasil sebagai berikut:

Tabel 8. Hasil Uji Korelasi

\begin{tabular}{ll|r|r} 
Correlations & & Terpaan Iklan & Citra Merek \\
\hline Terpaan Iklan & Pearson Correlation & 1 & $.426^{* *}$ \\
\hline & Sig. (2-tailed) & & .000 \\
\hline & $\mathrm{N}$ & 100 & 100 \\
\hline Citra Merek & Pearson Correlation & $.426^{* *}$ & 1 \\
\hline & Sig. (2-tailed) & .000 & \\
\hline & $\mathrm{N}$ & 100 & 100 \\
\hline \multirow{2}{*}{$*$ Correlation is significant at the O.o1 level (2-tailed) } \\
\multicolumn{2}{l|}{ Sumber: Data olahan penulis (2020) } \\
\end{tabular}

Hasil perhitungan hubungan korelasi variabel Terpaan Iklan (X) dan Citra Merek (Y) di atas menapilkan angka pada Sig. (2-tailed) sebesar 0,000 sehingga menjadi 0,000<0,05 yang mengindikasikan adanya hubungan antara kedua variabel tersebut. Hubungan antara variabel 
Terpaan Iklan dan variabel Citra Merek dengan angka koefisien korelasi Pearson sebesar 0,467 , yang bernilai positif berarti kedua variabel berkorelasi searah.

Tabel 9. Hasil Uji R-Square X terhaday Y dengan Responden Wanita dan Pria Model Summary

\begin{tabular}{|c|c|c|c|c|}
\hline Model & $\mathrm{R}$ & $R$ Square & $\begin{array}{l}\text { Adjusted } R \\
\text { Square }\end{array}$ & $\begin{array}{l}\text { Std. Error of } \\
\text { the Estimate }\end{array}$ \\
\hline 1 & $.377 a$ & 0,142 & 0,125 & 5,28171 \\
\hline \multicolumn{5}{|c|}{ a Predictors: (Constant), X Wanita } \\
\hline \multicolumn{5}{|c|}{ Model Summary } \\
\hline Model & $\mathrm{R}$ & $R$ Square & $\begin{array}{l}\text { Adjusted } R \\
\text { Square }\end{array}$ & $\begin{array}{l}\text { Std. Error of } \\
\text { the Estimate }\end{array}$ \\
\hline 1 & $.514 \mathrm{a}$ & 0,264 & 0,249 & 3,90733 \\
\hline
\end{tabular}

Nilai R pada tabel di atas menunjukkan hubungan antara terpaan iklan terhadap citra merek. Nilai R sebesar 0,377 dan 0,514, mengacu pada (Anwar, 2009, p. 104). menyatakan bahwa pada nilai tersebut terdapat tingkat hubungan korelasi rendah dan korelasi sedang. Dapat diinterpretasikan bahwa hubungan antara terpaan iklan terhadap citra merek berkorelasi rendah pada wanita dan berkorelasi sedang pada pria serta menunjukkan besarnya pengaruh variabel terpaan iklan terhadap citra merek.

Nilai Adjusted $R$ Square menunjukkan besarnya pengaruh terpaan iklan terhadap citra merek dilihat dari nilai koefisien determinasi yaitu sebesar 14,2\% terhadap citra merek pada konsumen wanita dan sisanya 85,8\% dipengaruhi faktor lain lalu terpaan iklan berpengaruh sebesar $26,4 \%$ terhadap citra merek pada konsumen pria dan sisanya $73,4 \%$ dipengaruhi faktor lain. Data ini menunjukkan hasil yang selaras dengan dua penelitan sebelumnya oleh Pratama \& Malau (2019) dan Adrian \& Nurhayati (2018) yang menunjukkan adanya pengaruh terpaan iklan terhadap citra merek.

Tabel 1o. Hasil Analisis Regresi Linear Sederhana X Terhadap Y Responden Wanita Coefficients ${ }^{\mathrm{a}}$

\begin{tabular}{rllrlrrr}
\hline Model & & $\begin{array}{l}\text { Unstandardized } \\
\text { Coefficients }\end{array}$ & & $\begin{array}{l}\text { Standardized } \\
\text { Coefficients }\end{array}$ & t & Sig. \\
\hline & & & & Std. \\
& & B & & Error & Beta & & \\
\hline 1 & & (Constant) & 29,870 & 2,851 & & 10,477 & 0,000 \\
\hline & X Wanita & 0,296 & 0,105 & 0,377 & 2,824 & 0,007 \\
\hline
\end{tabular}

a Dependent Variable: Y Wanita

Sumber: Data olahan penulis (2020)

Nilai konstanta (a) bertanda positif, dalam hal ini dengan besaran nilai 29,870, menyatakan bahwa nilai variabel Y (Citra Merek) bernilai positif jika tidak ada variabel X (Terpaan Iklan). Koefisien regresi (b) bertanda positif, dari data di atas dengan besaran nilai 0,296, menunjukkan adanya pengaruh positif antara Terpaan Iklan terhadap Citra Merek untuk responden wanita. 
Nilai $t_{\text {tabel }}$ dilihat pada taraf signifikansi o,o25 dimana $\mathrm{df}=5 \mathrm{O}-2=48$. Oleh karena itu nilai $t_{\text {tabel }}$ pada $\mathrm{df}=48$ adalah 2,011. Pada tabel di atas, diketahui bahwa besar $t_{\text {hitung }}$ variabel $\mathrm{X}$ (Terpaan Iklan) dan Y (Citra Merek) adalah 2,824 untuk konsumen wanita. Dengan demikian nilai $t_{\text {hitung }}$ sebesar 2,824 $>t_{\text {tabel }}$ 2,011 sehingga dapat disimpulkan $\mathrm{H}_{02}$ ditolak dan $\mathrm{H}_{2}$ diterima, maka variabel X (Terpaan Iklan) berpengaruh terhadap variabel Y (Citra Merek) dan besarnya beta (koefisien jalur) sebesar 0,377 pada konsumen wanita.

Tabel 11. Hasil Analisis Regresi Linear Sederhana X Terhadap Y Responden Pria Coefficients $^{\mathbf{a}}$

\begin{tabular}{|c|c|c|c|c|c|c|}
\hline Model & & $\begin{array}{l}\text { Unstandardized } \\
\text { Coefficients }\end{array}$ & & $\begin{array}{l}\text { Standardized } \\
\text { Coefficients }\end{array}$ & $\mathrm{t}$ & Sig. \\
\hline & & B & $\begin{array}{l}\text { Std. } \\
\text { Error }\end{array}$ & Beta & & \\
\hline \multirow[t]{2}{*}{1} & (Constant) & 25,120 & 2,545 & & 9,871 & 0,000 \\
\hline & $\mathrm{X}$ Pria & 0,398 & 0,096 & 0,514 & 4,154 & 0,000 \\
\hline
\end{tabular}

a Dependent Variable: Y Pria

Sumber: Data olahan penulis (2020)

Nilai konstanta (a) bertanda positif, dalam hal ini dengan besaran nilai 25,120, menyatakan bahwa nilai variabel Y (Citra Merek) bernilai positif jika tidak ada variabel X (Terpaan Iklan). Koefisien regresi (b) bertanda positif, dari data di atas dengan besaran nilai o,398, menunjukkan adanya pengaruh positif antara Terpaan Iklan terhadap Citra Merek untuk responden pria.

Dari tabel di atas, diketahui nilai $t_{\text {hitung }}$ sebesar 4,154 $>t_{\text {tabel }}$ 2,011 dan besarnya beta (koefisien jalur) sebesar 0.514 untuk konsumen pria. Sehingga, dapat disimpulkan $\mathrm{H}_{\mathrm{o}}$ ditolak dan $\mathrm{H}_{3}$ diterima, maka variabel X (Terpaan Iklan) berpengaruh terhadap variabel Y (Citra Merek) untuk konsumen pria.

Tabel 12. Hasil Uji t Independen

\begin{tabular}{|c|c|c|c|c|c|c|}
\hline & \multicolumn{3}{|c|}{$\begin{array}{c}\text { Levene's Test } \\
\text { for Equality of } \\
\text { Variance }\end{array}$} & \multirow[b]{2}{*}{$\mathrm{t}$} & \multirow[b]{2}{*}{ df } & \multirow[b]{2}{*}{ Sig. (2-tailed) } \\
\hline & & $\mathrm{F}$ & Sig. & & & \\
\hline \multirow{2}{*}{$\begin{array}{l}\text { Pengaruh Terpaan } \\
\text { Iklan Terhadap } \\
\text { Citra Merek }\end{array}$} & $\begin{array}{l}\text { Equal variances } \\
\text { assumed }\end{array}$ & 2,06 & .154 & 1,26 & 98 & .209 \\
\hline & $\begin{array}{l}\text { Equal variances } \\
\text { nor assumed }\end{array}$ & & & 1,26 & 95,3 & .209 \\
\hline
\end{tabular}

Sumber: Data olahan penulis (2020)

Terlihat dalam tabel di atas bahwa nilai $t_{\text {hitung }}$ adalah 1,26 . Nilai tabel dilihat pada taraf signifikansi 0,025 dimana $\mathrm{df}=50-2=48$. Oleh karena itu nilai $\mathrm{t}_{\text {tabel }}$ pada $\mathrm{df}=48$ adalah 2,011. Maka 1,26 $<2,011$ yang berarti $\mathrm{H}_{0}$ ditolak atau terdapat perbedaan signifikan rata-rata pengaruh terpaan iklan versi Shopee 9.9 super shopping day terhadap citra merek Shopee antara konsumen pria dan wanita. 


\section{SIMPULAN}

Dari hasil analisis dan jabaran atas hasil kuesioner yang sudah disebar pada responden pengguna aplikasi Shopee, maka berikut ini adalah simpulan dari masalah dan tujuan penelitian ini.

Pada uji korelasi menunjukkan adanya hubungan antara variabel Terpaan Iklan (X) terhadap Citra Merek (Y) yang termasuk dalam kategori korelasi rendah untuk responden wanita dan korelasi sedang untuk responden pria. Hasil analisis regresi penelitian menunjukkan bahwa koefisien regresi yang bertanda positif menunjukkan adanya pengaruh positif antara terpaan iklan terhadap citra merek. Dibuktikan juga dengan hasil uji $t$ dimana $t_{\text {hitung }}>t_{\text {tabel }}$ dan uji signifikansi dengan nilai Sig. $F$ sebesar 0,000 < 0,05 yang memiliki arti $\mathrm{H}_{2}$ dan $\mathrm{H}_{3}$ diterima atau variabel Terpaan Iklan (X) berpengaruh terhadap Citra Merek (Y) pada konsumen pria dan wanita. Kedua uji tersebut menunjukkan bahwa terdapat pengaruh antara terpaan iklan versi Shopee 9.9 Super Shopping Day Terhadap Citra Merek Shopee pada konsumen pria dan wanita.

Nilai Adjusted $R$ Square menunjukkan besarnya pengaruh terpaan iklan terhadap citra merek dilihat dari nilai koefisien determinasi yaitu sebesar 14,2\% terhadap citra merek pada konsumen wanita dan sisanya $85,8 \%$ dipengaruhi faktor lain lalu terpaan iklan berpengaruh sebesar $26,4 \%$ terhadap citra merek pada konsumen pria dan sisanya $73,4 \%$ dipengaruhi faktor lain. Hasil analisis regresi linear sederhana menunjukkan koefisien regresi sebesar sebesar 0,296 menyatakan bahwa besarnya pengaruh X (Terpaan Iklan) terhadap Y (Citra Merek) adalah 0,296 untuk responden wanita dan 0,398 menyatakan besarnya pengaruh X (Terpaan Iklan) terhadap Y (Citra Merek) adalah 0,398 untuk responden pria. Dari hasil tersebut juga menunjukkan bahwa pengaruh terpaan iklan pada konsumen pria lebih tinggi dibandingkan pengaruh terpaan iklan pada konsumen wanita yang berarti keinginan Shopee untuk menarik konsumen pria sudah terlaksana.

Hasil uji hipotesis uji $t$ (independen) menunjukkan nilai $t_{\text {hitung }} 1,26<$ nilai $t_{\text {tabel }}$ 2,011 yang berarti $\mathrm{H}_{01}$ ditolak atau terdapat perbedaan signifikan rata-rata pengaruh terpaan iklan versi Shopee 9.9 super shopping day terhadap citra merek Shopee antara konsumen wanita dan pria.

Berdasarkan hasil analisis penelitian, penulis menyimpulkan bahwa meskipun terdapat faktor-faktor lain yang dapat memepengaruhi citra merek, tetapi efek terpaan iklan yang diberikan oleh iklan Shopee 9.9 Super Shopping Day Cristiano Ronaldo memiliki pengaruh terhadap citra merek. Berdasarkan hal tersebut, kegiatan periklanan terhadap konsumen harus terus dijaga dan diperbaiki sebagai salah satu aspek cara menciptakan dan mempertahankan citra merek.

\section{DAFTAR PUSTAKA}

Adrian, S. W., \& Nurhayati, I. K. (2018). Pengaruh Terpaan Iklan Youtube Ramayana Ramadan 2017 Versi Bahagianya adalah Bahagiaku Terhadap Citra Merek. $e$ Proceedings of Management, 5(1), 1474-1480. 
Anwar, A. (2009). Statistika untuk Penelitian Pendidikan dan Aplikasinya dengan SPSS dan Excel. IAIT Press.

Arifin, J. (2017). SPSS 24 untuk penelitian dan skripsi. Elex Media Komputindo.

Batra, R., Myers, J. G., \& Aaker, D. A. (2006). Advertising Management (5th ed.). Pearson Education India.

Cicilia, M. (2019, Oktober 17). Ronaldo sukses mendongkrak penjualan Shopee. ANTARA News. $\quad$ https://kalteng.antaranews.com/berita/348768/ronaldo-suksesmendongkrak-penjualan-shopee

Firmansyah, M. A. (2019). Pemasaran produk dan merek (planning \& strategy). Penerbit Qiara Media.

Indrasari, M. (2019). Pemasaran \& Kepuasan Pelanggan. Unitomo Press.

iPrice Insight. (2019, July). Peta E-Commerce Indonesia [Data Sets]. iPrice. https://iprice.co.id/insights/mapofecommerce/

Kemp, S. (2020). Digital 2020: Indonesia [Data Sets]. Data Reportal. https://datareportal.com/reports/digital-2020-indonesia

Nurbani, P. A. (2016). Pengaruh Terpaaan Iklan E-Commerce Bukalapak di Televisi Terhadap Perilaku Konsumtif di Kalangan Mahasiswa Fakultas Ekonomi dan Bisnis UIN Syarif Hidayatullah Jakarta (Publication No. 32382) [Skripsi Sarjana, Universitas Islam Negeri Syarif Hidayatullah Jakarta]. UIN Syarif Hidayatullah Institutional Repository.

Payadnya, I. P. A. A., \& Jayantika, I. G. A. N. T. (2018). Panduan Penelitian Eksperimen Beserta Analisis Statistik dengan SPSS. Deepublish.

Pratama, V.A., \& Malau, R. M. U. (2019). Pengaruh Terpaan Iklan Televisi Shopee Versi Birthday Sale 12.12 Blackpink Terhadap Citra Merek (Publication No. 19.04.4988) [Skripsi Sarjana, Universitas Telkom]. Telkom Open Library.

Purnomo, R. A. (2017). Analisis Statistik Ekonomi dan Bisnis Dengan SPSS (3rd ed.). CV. WADE GROUP.

Raharjo, S. (2019, Januari 4). Cara melakukan Uji Validitas Product Moment dengan SPSS. SPSS Indonesia. https://www.spssindonesia.com/2014/o1/uji-validitas-productmomen-spss.html

Reza, J. I. (2015, Desember 01). Shopee, aplikasi belanja online c2c meluncur di Indonesia. Liputan6.com. https://www.liputan6.com/tekno/read/2379136/Shopee-aplikasibelanja-online-c2c-meluncur-di- indonesia 
Rita. (2018, Maret 27). Brand Image. BINUS Higher Education. https://bbs.binus.ac.id/gbm/2018/o3/27/brand-image/

Sari, P. S. (2019, Agustus 14). Gantikan BLACKPINK, Cristiano Ronaldo Jadi Brand Ambassador Shopee. iNews.id. https://www.inews.id/lifestyle/seleb/gantikanblackpink-christiano-ronaldo-jadi-brand-ambassador-shopee

Setiawan, N. (2005). Teknik sampling. Inspektorat Jenderal Departemen Pendidikan Nasional. content/uploads/2009/o3/teknik_sampling1.pdf http://pustaka.unpad.ac.id/wp-

Simamora, B. (2002). Aura Merek. PT. Gramedia Pustaka Utama.

Soenarso, S. A. (2019, April 05). Shopee jadi brand favorit wanita. Kontan.co.id https://amp.kontan.co.id/news/Shopee-jadi-brand-favorit-wanita

Suyono. (2018). Analisis Regresi untuk Penelitian. Deepublish.

Tashandra, N. (2018, Maret 22). 80 Persen Konsumen Belanja Online Orang Muda dan Wanita. Kompas.com. https://lifestyle.kompas.com/read/2018/o3/22/155001820/80-persen-konsumenbelanja-online-orang-muda-dan-wanita?page=all

Top Brand Award. (2020). TOP BRAND INDEX FASE 22020 [Data Sets]. Top Brand Award. https://www.topbrand-award.com/top-brandindex/?tbi_index=Top\%2oBrand\&tbi_year=2020

Triwijarnako, R. (2019, September 02). Shopee buka suara soal dampak iklan Cristiano Ronaldo. Marketeers.com. https://marketeers.com/shopee-buka-suara-soaldampak-iklan-cristiano-ronaldo

Widowati, H. (2019, April 25). Indonesia Jadi Negara dengan Pertumbuhan E-Commerce Tercepat di Dunia. Databoks. https://databoks.katadata.co.id/datapublish/2019/04/25/indonesia-jadi-negaradengan-pertumbuhan-e-commerce-tercepat-di-dunia 